\title{
Commentary: Longitudinal Rigid Sternal Fixation in high-risk patients: the optimal approach in the robotic era?
}

\author{
Caroline Komlo ${ }^{1}$, Colin Yost $^{2}$, and T. Sloane Guy ${ }^{1}$ \\ ${ }^{1}$ Thomas Jefferson University Hospital \\ ${ }^{2}$ Thomas Jefferson University
}

May 20, 2021

\section{Hosted file}

5.19 JCOS Commentary. Sternotomy closure LRSF in High Risk population .docx available at https://authorea.com/users/414828/articles/522754-commentary-longitudinal-rigid-sternalfixation-in-high-risk-patients-the-optimal-approach-in-the-robotic-era 